\title{
KONTRKULTURA W POLSCE - \\ FAKT CZY FIKCJA? \\ LATA 80. I 90. W WYPOWIEDZIACH \\ ANIMATORÓW KONTRKULTURY \\ NA ŁAMACH FANZINÓW
}

Bartosz Głowacki

Warszawska Wyższa Szkoła Humanistyczna

Polska kontrkultura z lat 80. dość wyraźnie różniła się od działań o charakterze kontrkulturowo-alternatywnym z następnej dekady nie tylko w kontekście zmiany pokoleniowej, ale przede wszystkim wyznawanych i realizowanych wartości. Innymi słowy, kontrkultura lat 80., w przeciwieństwie do działań z lat 90., była raczej młodzieżowym buntem w duchu liberalno-demokratycznym, który miał na celu nie tyle całościowe zakwestionowanie i przedefiniowanie dominującego paradygmatu społeczno-kulturowego, ile jedynie uzupełnienie go o elementy wykluczone przez system komunistyczny. Autentyczna kontrkultura, w tradycyjnym (zachodnim) tego słowa znaczeniu, zaczęła krystalizować się w Polsce dopiero w latach 90., gdy pojawiło się nowe, młodsze pokolenie aktywistów.

W literaturze przedmiotu istnieje konsens co do tego, że działania alternatywne i kontrkulturowe po roku 1989, czyli po przełomie transformacyjnym, były naturalną kontynuacją tego, co się działo w okresie PRL-u. Takie podejście wydaje się jednak nie do końca pokrywać z tym, co można znaleźć w zapomnianych dokumentach z epoki, jakimi są fanziny wydawane w drugiej połowie lat 80 . i na początku 90.

Dominujące obecnie w dyskursie na temat kontrkultury lat 80. różnego rodzaju retrospekcje, wspomnienia czy biografie daja jedynie częściowy i nie do końca prawdziwy obraz przeszłości przede wszystkim dlatego, że pisane sa z dzisiejszej perspektywy (np. Brylewski 2012, Grabowski 2010, Grabowski „Grabaż” 2010, Janiszewski, Konnak „Końjo”, Skiba 2010, Konnak 2012, Konnak 2013, Staszczyk 2011). W tej sytuacji wiele zdarzeń i opinii bywa zapominanych lub reinterpretowanych (np. nadaje się im nowe znaczenia polityczne), a pewnym zjawiskom i wydarzeniom przypisuje się większą rolę czy znaczenie, niż miały one w rzeczywistości, podczas gdy inne świadomie (lub nie) się pomija. 
Niniejszy tekst ma zatem dwa cele. Po pierwsze, stanowi próbę przedstawienia nowego podejścia do oceny polskiej kontrkultury z lat 80. i pokazania, że polską kontrkulturę lat 80. i 90. wiele kwestii nieraz fundamentalnie różniło. Liczne treści, które od lat 60. i 70. były obecne w działaniach kontrkulturowo-alternatywnych w Europie Zachodniej i USA, takie jak wartości postmaterialne i progresywne, antykapitalizm, kosmopolityzm, wielokulturowość, ekologia, feminizm, prawa mniejszości seksualnych czy etnicznych, nie pojawily się w Polsce aż do lat 90. I po drugie, takie postawienie problemu każe postrzegać zjawisko kontrkultury z lat 80. raczej jako typowy bunt młodzieżowy (pokoleniowy) niż jako klasyczną kontrkulturę.

Podstawowymi materiałami, na podstawie których powstał tekst, sa wspomniane już fanziny ukazujące się w Polsce na przełomie lat 80. i 90. Przez nikogo niekontrolowane, zachowujące całkowitą niezależność fanziny zawieraja unikatowy obraz ówczesnej kontrkultury. Gwarantuje to oczywiście wiele zalet, takich jak aktualność tematów i problemów opisywanych w danym okresie, luźny i szczery język, różnego rodzaju polemiki etc., ale równocześnie te same cechy mogą być także wadami. Brak dystansu, personalne animozje, wybiórczość tematyki to jedynie niektóre z nich. Przede wszystkim jednak fanzinom jako źródłu można zarzucić to, że były tworzone głównie przez osoby w danym środowisku najbardziej aktywne, przez co prezentuja selektywny obraz kontrkultury. Z drugiej jednak strony liczba osób zaangażowanych w tworzenie zinów sprawiła, że zawarty tam obraz jest bardziej autentyczny i egalitarystyczny niż większość współczesnych wspomnień pisanych przez pojedynczych liderów.

\section{/// Kontrkultura i kultura alternatywna}

Kontrkultura lat 60. XX wieku cechowała się zakwestionowaniem zasadności podstawowych założeń cywilizacji zachodniej, czyli tzw. paradygmatu miejsko-przemysłowego. Według Aldony Jawłowskiej kontestacja ta była ,zakwestionowaniem wszystkiego: kultury, polityki, organizacji społecznej, oczywistych form codziennej egzystencji, norm etycznych, wzorów i standardów zachowania. Całego sensu dotychczasowego istnienia" (1975: 10). I choć ruch ten nie doprowadził w krótkim czasie do istotnych zmian w obrębie żadnego zachodniego systemu politycznego, to jednak w dłuższej perspektywie przyczynił się do zmiany sposobu myślenia i oceny rzeczywistości, pozostawiając po sobie ,najbardziej wyraźne ślady w sferze kultury, światopoglądu, stylu życia, obyczaju, form ekspresji”' (tamże: 11), czego efektem były kolejne dekady, podczas których 
działalność kontrkulturowa i alternatywna stawała się doświadczeniem następnych pokoleń młodych ludzi.

W świecie zachodnim od połowy lat 70. płaszczyzną mobilizacji społecznej na szeroką skalę stały się tematy wcześniej prawie nietknięte przez konflikty społeczne. Były to kwestie ochrony środowiska, pacyfizmu, problemy jakości życia ujmowane w wymiarze ponadjednostkowym, krytyka kultury masowej, sprawy płci, zdrowia, regulacji urodzeń, autonomii lokalnej, uznania odrębności poszczególnych grup wiekowych, etnicznych itp. Niektóre z tych problemów, mających już za sobą okres inkubacyjny, nabrały w tym czasie jakościowo nowych cech (Gortat 1987: 42). Powstające wówczas różne ruchy, grupy i organizacje, w tym alternatywne partie polityczne (głównie ekologiczne), zaczęto określać mianem „nowych ruchów społecznych", a same działania kontrkulturowe coraz częściej zastępowano terminem ,kultury alternatywnej” (niezależnej). Innymi słowy, w pewnym uproszczeniu można powiedzieć, że kontrkultura ma raczej miejsce na wczesnym etapie protestów (buntu), po czym następuje stadium swego rodzaju instytucjonalizacji działań (choć nadal na wielu płaszczyznach nieformalnych), które bardziej pasują do formuły kultury alternatywnej.

Owa tzw. kultura alternatywna korzystała w dużym stopniu z krytycznego przemyślenia doświadczeń kontrkultury i nadziei związanych z pokoleniem '68 roku. Ta uformowana, odrębna, pozostająca poza głównym nurtem życia społecznego „kultura alternatywna” umożliwiała realizowanie się właściwie we wszystkich dziedzinach codziennego życia. Rozkwit tej działalności przypadł na lata 80. XX wieku, kiedy miał miejsce niespotykany wcześniej rozwój alternatywnych sieci oraz autonomicznych form działania i organizacji. Działania oparte na formule DIY (ang. „Do It Yourself" - zrób to sam) umożliwiły autentyczną zmianę - nie tylko w skali jednostkowej - tak prozaicznych rzeczy, jak sposób mieszkania, zdobywania i przygotowywania żywności, zarabiania i wydawania pieniędzy, spędzania wolnego czasu, wychowywania i edukowania dzieci w inny sposób, niż czynił to ogól, ale także w szerszym zakresie: sieć DIY umożliwiła wykształcenie się autentycznej, niezależnej od oficjalnych kanałów kultury. Innymi słowy, wyodrębnił się całościowo odmienny sposób egzystencji widziany w perspektywie życia codziennego. Ważne zaczęły być nie stopień zamożności osobistej (charakterystyczny dla społeczeństw kultury zachodniej), lecz wyznawane i realizowane wartości. Kontrkultura i późniejsza kultura alternatywna to przejaw tej samej kumulującej się tendencji społeczno-kulturowej, tego samego kierunku przemian wartości, które zaprzeczaja podstawowym znaczeniom dominującego paradygmatu cywilizacyjnego. Jak zauważa Anna Wyka: „Nie jest to zatem niedojrzały 
bunt, w którym jest się jedynie przez negację zależnym od wartości dominujących, ale świadome, efektywne i systematyczne działanie według obranych wzorów we wszystkich sferach codzienności. Dlatego w teorii zjawiska mówi się o alternatywnych stylach życia, kulturze alternatywnej i alternatywnym światopoglądzie" (1987: 9-10).

Jasne rozdzielenie zjawiska kontrkultury i kultury alternatywnej nie jest dzisiaj proste, albowiem oba te obszary zaczęły się z czasem przenikać, wyraźne kiedyś między nimi różnice - zacierać, a sami animatorzy tych zjawisk używają tych pojęć wymiennie. Sytuacji nie ułatwia także to, że zarówno kontrkultura, jak i kultura alternatywna były kiedyś kojarzone z kulturą młodzieżową i młodzieżowymi subkulturami, które współcześnie sa częścią szeroko rozumianej mainstreamowej kultury popularnej. Same początki kultury młodzieżowej sięgają wczesnych lat 50. XX wieku i fenomenu muzyki rockandrollowej. Już wtedy kultura młodzieżowa miała charakter zarówno autentycznie oddolny, jak i odgórnie generowanej mody. Z kolei termin ,subkultura” początkowo był używany do określania środowisk kryminogennych, dopiero od lat 60. zaczęto używać go również w odniesieniu do grup młodzieżowych wyrosłych z kultury (głównie muzyki popularnej). Zarówno „kultura młodzieżowa”, jak i „subkultura” sa jednak pojęciami niewystarczającymi, by mogły dzisiaj służyć do omówienia opisywanych w tekście zjawisk, gdyż są zbyt rozmyte i nazbyt szerokie.

W polskich realiach pierwsze masowe oznaki młodzieżowej kontrkultury i kultury alternatywnej pojawiły się dopiero w latach 80. wraz z wykształceniem się prawdziwej (zarówno mainstreamowej, jak i oddolnej) kultury młodzieżowej, co w literaturze przedmiotu określa się za pomocą pojęcia „trzeci obieg”.

\section{/// Trzeci obieg}

Autentycznie oddolna i niezależna kultura młodzieżowa na dużą skalę zaczęła rozwijać się w Polsce w latach 80. Skala zjawiska nie miała sobie równych we wcześniejszych latach (choć warto podkreślić, że nadal była to mniejszość polskiej młodzieży) i, co więcej, działo się to w dużym stopniu poza oficjalnym obiegiem kultury. Było to związane przede wszystkim ze skutkami gwałtownego rozwoju muzyki rockowej w latach 1980-1984 - popularnie nazywanego „boomem polskiego rocka” (Gnoiński, Skaradziński 2001: 88-90) - i związanego z tym kształtowania się właściwej, bo oficjalnie akceptowanej, kultury młodzieżowej. Przejawiało się to chociażby w tym, że już na przełomie lat 70. i 80. pojawiły się nowe czasopisma, audycje radiowe i telewizyjne poświęcone wyłącznie młodym ludziom. 
Popularność mainstreamowego, zaakceptowanego przez mass media rocka sprawiła, że wraz z nim pojawili się wykonawcy, którzy z różnych powodów (deklarowanej niezależności, buntu, braków warsztatowych etc.) w tym oficjalnym nurcie nie chcieli lub nie mogli zaistnieć. Z czasem, w drugiej połowie lat 80., doprowadziło to do gwałtownego rozwoju muzyki z obszaru tzw. rocka alternatywnego (niezależnego).

Temu wszystkiemu towarzyszyły zjawiska z kręgu kultury młodzieżowej. Duża część z nich siłą rzeczy zaczęła funkcjonować w odrębnym obiegu kultury. W dużym stopniu było to możliwe dzięki zmianom, jakie zaszły w Polsce na początku dekady. Powstanie i legalizacja Solidarności sprawiły, że w działalność społeczną, kulturalną czy polityczną zaangażowało się wielu młodych ludzi. Nie bez znaczenia była także ogólna sytuacja geopolityczna, a szczególnie zmiany, jakie w polityce ZSRR wprowadził nowy przywódca Michaił Gorbaczow (głasnost i pieriestrojka), co nie pozostało bez wpływu na sytuacje w krajach bloku wschodniego. To wszystko sprawiło, że z jednej strony bariery, które wcześniej stwarzał system komunistyczny, wyraźnie osłabły, a z drugiej wzrosła bezkompromisowość młodego pokolenia.

Innym często pomijanym, a niezmiennie ważnym w kontekście Polski czynnikiem było pojawienie się w przestrzeni publicznej nowinek technicznych, w tym pierwszych kserokopiarek i przenośnych magnetofonów kasetowych, co złamało monopol środków masowego przekazu na informacje i państwowych firm fonograficznych na nagrania. Kasety nagrywane na przenośne magnetofony na koncertach, a potem przegrywane w domu, umożliwiały niezależną komunikację wśród młodzieży (Wertenstein-Żuławski 1987: 24).

W tych warunkach w latach 80 . wyodrębnił się tzw. trzeci obieg kultury. W systemach demokratycznych mamy do czynienia z dwoma obiegami - oficjalnym i nieoficjalnym (alternatywnym, niezależnym lub tzw. undergroundowym). W realiach PRL-u ten klasyczny układ nie do końca się sprawdzał, albowiem pierwszym obiegiem była całość kultury oficjalnej rozpowszechnianej za pomocą mass mediów, którą kontrolowało (w mniejszym lub większym stopniu) państwo. Drugi obieg został powołany do życia przez opozycję demokratyczną w połowie lat 70. i miał na celu nie tylko eksponowanie przeciwnej opcji politycznej, lecz także uzupełnienie obiegu oficjalnego o te pozycje, które nie miały szans ukazać się ze względów pozaartystycznych (najczęściej politycznych). Zatem wartości obecne w drugim obiegu w PRL-u w społeczeństwach rządzonych demokratycznie uchodziłyby za tradycyjne (pierwszoobiegowe). Dlatego - chociaż w opozycji - drugi obieg nie był przeciwny całości zastanej 
kultury, nie zamierzał też zrewoltować obyczajowości czy dominujących gustów estetycznych (Pęczak 1988b: 172).

Tego zadania, według wielu badaczy (por. m.in. Jesswein 1985, Pęczak 1988, Fatyga 1999, Idzikowska-Czubaj 2006), miał podjąć się dopiero trzeci obieg, który stanowił ewidentną reakcję na kulturową rzeczywistość ówczesnych czasów i wpisał się jako specyficzna (alternatywna, a w niektórych przypadkach także kontrkulturowa) forma komunikacji. Mirosław Pęczak uważa, że trzeci obieg zaproponował inny sposób formułowania myśli, inną wrażliwość czy wreszcie hierarchię wartości (1988a: 35). Barbara Fatyga dodaje, że skupiał on problemy lekceważone przez „dorosłe" społeczeństwo nie tylko w pierwszym, lecz także w drugim obiegu. Najważniejszymi według niej cechami tego obiegu były negacja, dystans i niezwykła dynamika, która najczęściej przybierała formę efemeryczności działań (1999: 94).

W związku z tym trzeci obieg funkcjonował głównie na marginesie kultury oficjalnej, czyli tej promowanej przez państwo, a zarazem w innym obszarze i na innych zasadach niż nielegalny drugi obieg. Jak zauważa Anna Idzikowska-Czubaj, ,ów trzeci obieg z odbijanymi na ksero gazetkami, a zwłaszcza z muzyką rockową niosącą buntowniczy przekaz, stworzył z czasem naszą rodzima, niezwykle ciekawą wersję kultury alternatywnej” (2006: 287-288).

Aktywność w trzecim obiegu nie wiązała się z posiadaniem państwowych pozwoleń na sprzedaż czy rozpowszechnianie, bo często nawet o to nie zabiegano. Równocześnie jednak osoby zaangażowane w tę działalność same nie ponosiły z tego powodu jakichś szczególnych konsekwencji, bo najczęściej ich działalność była po prostu bardzo ograniczona lub z perspektywy aparatu państwowego zupełnie nieistotna albo niegroźna. Paradoksalnie jednak spora część tej trzecioobiegowej aktywności była obecna w oficjalnym (pierwszym) obiegu. Część zespołów po przejściu przez cenzorskie sito wydawała płyty w oficjalnych (państwowych) wytwórniach płytowych (innych nie było), była dopuszczana do oficjalnych mediów, głównie prasy muzycznej i młodzieżowej (np. „Non Stop”, „Magazyn Muzyczny”, „Na przełaj”), radia (Program III PR czy pasmo młodzieżowe w Programie IV PR w ramach Rozgłośni Harcerskiej), filmów fabularnych (np. Caly ten rock) i dokumentalnych (np. Fala, Koncert), wreszcie zbuntowani wykonawcy uczestniczyli w szeregu festiwali, przeglądów czy koncertów organizowanych przez oficjalne organizacje młodzieżowe, domy kultury, kluby studenckie etc. (najbardziej znany to Festiwal Muzyków Rockowych w Jarocinie). 
Z punktu widzenia tych rozważań istotne jest wyodrębnienie się trzeciego obiegu w kontekście kształtowania się kultury punk w Polsce. Właśnie w odniesieniu do tego zjawiska Rafał Jesswein jako pierwszy w Polsce użył terminu ,trzeci obieg” (1985). Mimo że termin ten został utworzony i zdefiniowany przez socjologów, stosunkowo szybko posłużył do opisywania zjawisk związanych z oddolną działalnością młodych ludzi i co więcej, został przez nich zaakceptowany i był używany do końca lat 90 .

W Polsce kultura punk, wzorując się na działalności swoich rówieśników na Zachodzie, stworzyła szereg środków, za pomocą których można było wyrażać swoje poglądy i zachowania niemieszczące się w kanonie kultury oficjalnej i tradycyjnej. Młodzi ludzie zaangażowani w punk zaczęli wydawać własne gazetki, nagrywać i rozprowadzać kasety, organizować koncerty (co wiązało się ze zorganizowaniem sali i sprzętu, przygotowaniem i rozklejeniem plakatów reklamowych, zapewnieniem noclegu i wyżywienia dla muzyków etc.), własnym sumptem robić koszulki z nadrukowanymi hasłami czy nazwami zespołów, a wreszcie komponować piosenki i pisać do nich teksty, bardzo często o charakterze politycznym.

W trzecim obiegu znalazły się więc te zespoły, które najczęściej nie miały szans na zaistnienie w obiegu pierwszym. W latach wcześniejszych taka postawa równała się zazwyczaj samounicestwieniu, gdyż nie istniały w zasadzie inne (poza koncertami) możliwości zdobycia popularności. W latach 80. dzięki trzeciemu obiegowi sytuacja znacząco się zmieniła i wiele zespołów było znanych jedynie z niezależnego obiegu kaset. Nagrywano je na koncertach lub w chałupniczych warunkach, a następnie powielano w domach. Potem krążyy one po całej Polsce wśród określonego grona wtajemniczonych.

Zatem głównymi nośnikami nurtów alternatywnych w Polsce stały się kasety magnetofonowe $z$ muzyką oraz papierowe fanziny.

\section{/// Xeroferia, czyli fanzinowe szaleństwo}

W latach 80. i 90. fanziny w Polsce stały się istotnym nośnikiem alternatywnych treści światopoglądowych. W praktyce każdy mógł je współredagować, wystarczyło tylko nawiązać kontakt z redakcją i wysłać artykuł, lub samodzielnie wydawać. Tym samym oznaczało to akces do wspólnego tworzenia wartości. Zniesiony został podział na tych, którzy pisza (tworza), i na tych, którzy czytaja (konsumuja) (Idzikowska-Czubaj 2006: 289-290).

Do Polski idea fanzinu (oryginalnie z ang. „fanzine”, czyli połączenie dwóch słów: „fan” i „magazine”, w skrócie „zine”; w Polsce przyjęła się 
spolszczona wersja - odpowiednio: fanzin i zin) przywędrowała z Zachodu pod koniec lat 70 .

Fanzin to gazetka przygotowywana i wydawana według idei DIY, poza oficjalnym obiegiem, najczęściej przez jedną osobę (pełniącą wszystkie redakcyjne funkcje: autora tekstów, redaktora, grafika, korektora, dystrybutora itp.). Ważnym elementem, który odróżnia fanzin od klasycznej gazety, jest również to, że jego twórca świadomie chce pozostać poza oficjalnymi kanałami redystrybucji kultury.

Ziny najczęściej powstawały wtedy, gdy tematyka, którą podejmowały, nie była poruszana przez media głównego nurtu. Jest to szczególnie istotne w odniesieniu do polskich realiów lat 80., czy może nawet bardziej okresu tuż po przełomie. Pozostanie poza mainstreamem było niejako sygnałem, że młodzi ludzie (a przynajmniej ich część) nie identyfikowali się ani z systemem komunistycznym, ani z obejmującymi po nim władzę ludźmi z szeroko rozumianej byłej opozycji demokratycznej.

Wreszcie ostatnia kwestia wyróżniająca klasyczne fanziny to formuła non profit. Idee tam reprezentowane były ważniejsze niż ewentualne zyski - to miało sens w realiach PRL-u, gdy jakakolwiek działalność niekoncesjonowana przez państwo była zakazana. Po przełomie, gdy wszystko to, co niezakazane, było dozwolone, trzymanie się powyższych założeń sugerowało chęć tworzenia czegoś nowego i na swój sposób unikalnego.

Pierwsze fanziny pojawiły się w latach 30 . XX wieku w USA wśród fanów literatury science fiction. Początkowo komunikowali się oni poprzez ogłoszenia i działy listów w magazynach poświęconych literaturze s.f., a z czasem przenieśli te dyskusje do samodzielnie wydawanych czasopism. W kolejnych latach praktycznie każdy nowy nurt w kulturze czy jakiekolwiek działania o charakterze społecznym miały swoje własne niezależne wydawnictwa. Szczególne nasilenie tego zjawiska miało miejsce w okresie kontrkultury lat 60. (w czym pomogło pojawienie się kserokopiarek), a masowe upowszechnienie samych fanzinów nastapiło w drugiej połowie lat 70. przy okazji eksplozji muzyki punk, poczattkowo w Wielkiej Brytanii i USA, a zaraz potem na całym świecie.

W polskich realiach fanzinowy boom związany jest bezpośrednio właśnie ze zjawiskiem punk rocka, czyli gatunku z obszaru muzyki rockowej, który narodził się równolegle w USA i Wielkiej Brytanii w latach 1976-1977, a do Polski dotarł około roku 1978. Punk rock był pierwszym gatunkiem muzyki popularnej tak mocno związanym z oddolnym zaangażowaniem młodych ludzi - fanów. Obok słuchania samej muzyki nie tylko angażowali się twórczo w jej tworzenie, lecz także podejmowali działania około- i pozamuzyczne, w tym polityczne, społeczne, ekologiczne itp. 
Jedną $z$ takich aktywności było własnoręczne tworzenie przez samych fanów gazetek - fanzinów. Pisano w nich o nowej muzyce, nowych zjawiskach $z$ nią związanych, wymieniano adresy i informacje, słowem, podejmowano te wszystkie tematy, o których nie chciały pisać (lub których nie dostrzegały) oficjalne fachowe magazyny muzyczne. Fanziny tworzyli młodzi ludzie w przedziale wiekowym 15-25 lat, pisali je takim językiem, jakim posługiwali się na co dzień, i kierowali je przede wszystkim do swoich rówieśników.

Pierwsze fanziny zaczęły ukazywać się w Polsce już pod koniec lat 70. głównie w Warszawie i Gdańsku, czyli miastach, w których działały pierwsze zespoły punkowe. Ówczesne ziny miały bardzo waskie grono odbiorców, wychodziły w bardzo małych nakładach, głównie dla przyjaciół i najczęściej jako pojedyncze numery (duży wybór reprodukcji fanzinów z tego okresu: Dąbrowska-Lyons 1999). Kolejny okres dużej aktywności młodych ludzi tworzących fanziny przypadł na czasy tzw. drugiej fali polskiego punk rocka, czyli lata 1981-1983, będące równocześnie czasem stanu wojennego.

Okres ten charakteryzował się przede wszystkim tym, że ówczesne fanziny tworzone były przez osoby wywodzące się z samych zespołów lub ich bliskiego otoczenia oraz że ich twórcy po raz pierwszy zaczęli nawiązywać bezpośrednie kontakty z podobnymi wydawnictwami zza żelaznej kurtyny. Jednym z bardziej znanych fanzinów ukazujących się w tym okresie był „Azotox”, wydawany przez członków warszawskiej grupy Dezerter i darmowo rozprowadzany wśród znajomych (Grabowski 2010: 297-334).

Jednak gwałtowny i masowy wysyp fanzinów w Polsce przypadł na okres od końca 1988 r. do końca lat 90., ze szczególnym nasileniem w latach 1989-1995. Wpłynęło na to wiele czynników, z których najistotniejsze to:

(a) upadający system komunistyczny z całym swoim aparatem represji nie był już tak silny i nie był w stanie kontrolować wszystkich obszarów życia społecznego;

(b) przemiany systemowe stworzyły całkowicie nowe realia. Przyszłość (nawet ta najbliższa) była nieprzewidywalna, a tradycyjne media nie nadażały z tłumaczeniem zachodzących zmian. Rodziło to głód informacji, szczególnie w obszarach pomijanych w dyskursie publicznym (jak np. problemy młodych ludzi), i stwarzało dobre warunki do rozwoju niezależnych źródeł informacji, jakimi były fanziny;

(c) wraz z deregulacją rynku pojawiły się nowe możliwości, chociażby w obrębie środków technicznych (prywatne i legalne punkty ksero, 
legalny dostęp do papieru, komputery etc.) umożliwiających powielanie gazetek;

(d) last but not least, na przełomie lat 80. i 90. wśród słuchaczy i muzyków z kręgu kultury punk pojawiła się bardzo prężna grupa próbująca robić coś więcej, niż tylko siedzieć, pić i narzekać. Najczęściej identyfikowali się oni z jednym z podgatunków punk rocka, jakim był hardcore. Ci młodzi ludzie nie chcieli bezczynnie siedzieć i przyglądać się temu, co działo się dookoła nich, ale autentycznie się zaangażować. Było to szczególnie widoczne po przełomie 1989 roku, gdy próbowano tworzyć coś nowego, niezależnego zarówno wobec upadającego reżimu, jak i zastępujących go nowych elit. Tworzono zatem klasyczną kulturę alternatywna, świadomie pozostająca poza oficjalnym (teraz już także wolnym) obiegiem. Elementem charakterystycznym dla wielu młodzieżowych ruchów kontrkulturowych z początku lat 90 . był brak akceptacji jakichkolwiek organizacji politycznych. Były one z natury antyinstytucjonalne, a wszystkie istniejące organizacje formalne traktowały jako rdzeń „systemu”, który zagrażał realizacji ważnych wartości jednostkowych (Lenart 1993: 194).

Samodzielne tworzenie fanzinów gwarantowało pisanie o tym, o czym się myślało, bez zwracania uwagi na to, czy jest to dozwolone, czy nie, czy zachowane są odpowiednie słownictwo, pisownia lub konwenanse. W duchu kontrkultury łamano kanony, prowokowano, stawano w kontrze do kultury zastanej. W trzecim obiegu funkcjonowało specyficzne słownictwo młodzieżowe - w latach 1980-1981 nastapił rozwój slangu młodzieżowego, często niezrozumiałego dla starszego pokolenia. Język ten obfitował w wulgaryzmy, był bezkompromisowy i dosadny. Odzwierciedlał przemiany cywilizacyjno-obyczajowe, jakie zachodziły w Polsce w końcu lat 70., przez całą dekadę lat 80. i 90. Ten szczególny rodzaj języka był wykorzystywany w tekstach utworów rockowych i fanzinach, wyrażał poglady, sposób myślenia i przeżywania młodego człowieka (badaniem języka fanzinów z lat 1995-1998 zajmował się m.in. Kajtoch 1999). Szargano w nim narodowe i religijne wartości, łamano stereotypowe przyzwyczajenia, wyrażano okrucieństwo czasów współczesnych, tworzono swoista poetykę szarości i niezgody na nią (Idzikowska-Czubaj 2006: 290).

Język fanzinów był językiem tych, którzy je tworzyli, i tych, którzy je czytali. W pewnym sensie przypominało to dzisiejsze fora internetowe, gdzie charakterystyczna dla tradycyjnych mediów jednokierunkowa zasada „od nadawcy do odbiorcy” została zastapiona traktowaniem nadawców i odbiorców jako równorzędnych partnerów w procesie tworzenia 
i upowszechniania treści medialnych. Język i zawartość fanzinów zachęcały (często wręcz wzywały) do działania i aktywności, przy czym fanziny z początku lat 80 . charakteryzowały się większą hasłowością i lakonicznościa, podczas gdy z upływem czasu coraz większego znaczenia zaczęły nabierać dłuższe teksty.

Fanziny z okresu przełomu gwarantowały poczucie całkowitej wolności i swobody. A przede wszystkim przekazywały informacje, co w społeczeństwie z ograniczoną liczbą kanałów dystrybucji wiadomości miało kolosalne znaczenie. Siła tych wszystkich pisemek brała się stąd, że wydawano je poza zasięgiem urzędu cenzury. Niekontrolowane przez nikogo mogły umieszczać teksty, których nie można było spotkać w zwykłej, dostępnej w kiosku prasie - zawierały treści dotyczące spraw, o których wielu obywateli nie miało pojęcia. Jak zaważył jeden z obserwatorów tego zjawiska, niezależność tych pism od cenzury wychodziła czytelnikom jedynie na dobre (Szczygieł 1989: 9).

Do najciekawszych fanzinów z tamtego czasu, ukazujących się cyklicznie i mających wpływ na cała scenę zinowa, należały: punkowo-hardcore'owe „QQRYQ” z Warszawy, „Antena Krzyku” z Wrocławia, „A-Tak” z Poznania, „Kanaloza” z Bydgoszczy, „O.K.-urde” z Piły, „Ciach-zine” z Grodziska Mazowieckiego, „Woda” z Bytomia, „Truposz” z Zielonej Góry, „Anfall” z Białej Podlaskiej; anarchistyczne i z pogranicza anarchizmu „Przegięcie Pały” z Lodzi, „Мать Парядка” („Mać Pariadka”) z Sopotu, „Homek” z Gdańska, „Rewolta” z Warszawy, „Kultura Nędzy” z Lublina, „Apolitik” z Ełku, artystyczne „Linie” i „Iskra Boża” z Warszawy, ekologiczne i z pogranicza ekologii „Zielone Brygady” z Krakowa, „Greencore” z Poznania, „Trująca Fala z Truj-miasta”, komiksowe „Zakazany Owoc” z Lublina, „Prosiacek” z Katowic, „AQQ” z Poznania, wydawnictwo ruchu Wolność i Pokój - „A-Capella” z Krakowa czy feministyczne „Czarna Suko” ze Szczecina i „Wiedźma” z Lukowa/Siedlec.

Oszacowanie całości zjawiska nastręcza szereg problemów, takich jak efemeryczność, przypadkowość i różny zasięg oddziaływania. To wszystko sprawia, że dokładne określenie liczby wydawanych w trzecim obiegu tytułów (nie wspominając o nakładach i ilości czytelników - jeden egzemplarz był zazwyczaj czytany przez kilka-kilkanaście osób) jest w zasadzie niemożliwe. Według bardzo ostrożnych szacunków (Ciosmak 2001) można przyjać, że w okresie 1988-1999 wychodziło łącznie od 1500 do ok. 2000 tysięcy tytułów pisemek w całości niekontrolowanych i pozostających poza oficjalnym obiegiem, a redagowanych przez młodych ludzi.

Oczywiście gwałtowność i zasięg zjawiska doprowadziły do jego umasowienia i ogromnej popularności. Obok fanzinów punkowych, hard- 
core'owych, anarchistycznych czy ekologicznych pojawiły się ziny polityczne, artystyczne, literackie, poetyckie, komiksowe, poświęcone graffiti, duchowości, religiom Wschodu, antyklerykalne, nacjonalistyczne, kibicowskie etc. Zainteresowały się nimi również media oficjalne, głównie młodzieżowe, jak tygodnik dla młodzieży szkolnej „Na przełaj”, czy oficjalne pisma muzyczne, np. miesięcznik „Non Stop”, który przez pewien czas swoją szatę graficzną wzorował na chaotycznej formie fanzinów. Wywołało to szereg protestów i ostrych komentarzy, na przykład „Pietia” (Piotr Wierzbicki) na łamach „QQRYQ” pisał: „«Na przełaj» tworzy pozór jakiejś bliżej nieokreślonej alternatywy, która przy bliższym przyjrzeniu okazuje się jeszcze jednym szwindlem. [...] Są bezpieczni, ulegli, grzeczni, a jeśli już do czegoś się biora, to wychodzi z tego pustka, lub żenująca bufonada" (1989: 3-4).

To podkreślanie niezależności i alternatywności (oraz w pewnym sensie elitarności), tak ważne dla ruchów kontrkulturowych, musiało zderzyć się ze zmieniającymi się realiami politycznymi, społecznymi i ekonomicznymi w przechodzącej transformację Polsce. Zmianom tym poddała się również część środowiska trzeciego obiegu i mniej więcej od około roku 1994 kolejne tytuły legalizowały swoją działalność, profesjonalizowały się czy wreszcie sięgały po oficjalne formy dystrybucji (kioski, Empiki etc.), stając się (przynajmniej na papierze) prywatnymi przedsiębiorstwami prowadzącymi działalność wydawniczo-handlową.

Z całej sceny fanzinowej w Polsce na uwagę zasługują szczególnie trzy tytuły, które wywarły wpływ nie tylko na środowisko zinowe, lecz także na polską kontrkulturę przełomu lat 80. i 90. Chodzi tutaj o warszawski fanzin „QQRYQ” (czyt.: kukuryku), który na wiele lat stał się wzorem dla polskich zinów, krakowskie „Zielone Brygady”, które funkcjonowały jako skrzynka kontaktowa dla środowisk ekologicznych, wolnościowych czy pacyfistycznych, i wreszcie trójmiejski zin „Мать Парядка” („Мас́ Pariadka”), który stał się platformą do wymiany poglądów i opinii osób zaangażowanych w polską kontrkulturę. Nie bez znaczenia jest także fakt, że wszystkie trzy periodyki ukazywały się przez dłuższy czas i miały jak na fanzinowe realia duże nakłady oraz szerokie grono współpracowników. W związku z tym opinie i treści tam prezentowane można traktować jako reprezentatywne dla całego środowiska kontrkulturowo-alternatywnego z tamtego okresu.

„QQRYQ” ukazywało się od 1986 do 1993 roku (w sumie 18 numerów) i jak zdecydowana większość fanzinów w trakcie swojego istnienia miał różną szatę i jakość graficzną (od powielaczy, przez ksero, po offset) oraz objętość (od kilku stron formatu A5 w pierwszych numerach do ok. 68-88 stron formatu B5 w ostatnich). W czasie przełomu był to najbardziej 
znany i posiadający największy zasięg oraz nakład polski fanzin. Gazeta od początku tworzona była przez jedną osobę - „Pietię” (Piotr Wierzbicki - zbieżność imienia i nazwiska z założycielem „Gazety Polskiej” całkowicie przypadkowa), którego z czasem zaczęli wspierać Zbyszek (Zbigniew Matera) i „Stasiek” (Darek Stewula). „QQRYQ” wyróżniało się stosunkowo staranną i przejrzystą jak na fanzinowe standardy szata graficzną i layoutem. Przypominal on typowa gazetę, podczas gdy zdecydowana większość zinów w tamtym czasie była pod tym względem mocno chaotyczna (by nie powiedzieć nieczytelna) i opierała się na swobodnym, kolażowym łączeniu fragmentów tekstu, zdjęć czy rysunków. Także zawartość pisma, dość wyraźnie wzorowana na amerykańskim fanzinie „Maximumrocknroll”, prezentowała się na tle innych zinów wyjątkowo ciekawie. Od początku składały się na nią dział felietonów (zatytułowany „Kolumny”, które z czasem zaczęły pisać także osoby spoza redakcji), informacje i wywiady z zespołami (także zagranicznymi), relacje z koncertów, raporty na temat funkcjonowania scen punkowych (ale także wszelkich działań o alternatywnym charakterze) w różnych miastach Polski oraz świata, rysunki satyryczne (o różnej tematyce - od polityki po zdarzenia z życia młodych ludzi czy kontrkultury, rysowane przez zaprzyjaźnionych z redakcją młodych rysowników), artykuły o wegetarianizmie, squattingu czy zastępczej służbie wojskowej itp. W miarę jak fanzin się rozrastał, przybyły: dział listów od czytelników (aczkolwiek redakcja zdecydowała się na podanie swojego adresu na łamach pisma dopiero w numerze $15 \mathrm{z}$ czerwca 1990 roku), minikomiksy, recenzje płyt i fanzinów czy wreszcie reklamy. W latach 80 . zasięg pisma był dość ograniczony i opierał się na dystrybucji pocztowej oraz podczas koncertów. W pierwszym przypadku do fanzinu mogli dotrzeć tylko ludzie, którzy znali kogoś, kto znał adres redakcji, a w drugim - tylko ci, którzy chodzili na wybrane koncerty (najlepiej organizowane przez osoby tworzace „QQRYQ” lub z nim współpracujace). Po przełomie nakład pisma wzrósł do ok. dwóch tysięcy, choć same formy dystrybucji się nie zmieniły.

„Zielone Brygady” w zasadzie nigdy nie miały charakteru klasycznego fanzinu, ale od początku były kojarzone z tym środowiskiem. Pismo powstało w 1989 roku na Wydziale Chemii Uniwersytetu Jagiellońskiego w ramach wydziałowego Koła Chemików, a tworzyli je aktywni w nim studenci zainteresowani ochroną środowiska. Stosunkowo szybko magazyn stał się nieoficjalną skrzynką kontaktową polskiego ruchu ekologicznego (zarówno tego oficjalnego, jak i alternatywnego) i różnych środowisk o charakterze pacyfistycznym, anarchistycznym, kontrkulturowym i alternatywnym. Formuła tworzenia pisma nie zmieniła się w zasadzie przez 
kolejnych kilkanaście lat, tzn. w całości oparta była na nadsyłanych materiałach. Praktycznie przez cały okres istnienia pisma (do 2008 roku wyszło w sumie ponad 230 numerów) ukazywało się ono w formie zeszytów formatu A5 (od około 30 do prawie 100 stron), a od końca lat 90. wszystkie numery dostępne były także w formie cyfrowej.

Anarchistyczno-muzyczny fanzin „Мать Парядка” (w 1999 roku spolszczono pisownię tytułu na „Mać Pariadka”) ukazywał się w Sopocie od 1990 do 2002 roku (łącznie ponad 80 numerów). Został powołany do życia przez ludzi związanych z trójmiejską kontrkulturą lat 80. (głównie przez osoby związane z Ruchem Społeczeństwa Anarchistycznego ${ }^{1}$ i Ruchem Wolność i Pokój ). „Мать Парядка” była jednym z pierwszych fanzinów, który w połowie lat 90. trafił do legalnej dystrybucji. Jego autorzy potrafili także utrzymać regularny (miesięczny) cykl wydawniczy i dzięki temu fanzin na swój sposób zdominował na kilka lat scenę niezależnej prasy. Główna idea stojąca za magazynem to prezentacja szeroko rozumianego spektrum współczesnej myśli anarchistycznej i wolnościowej (stąd podtytuł „Wolny Magazyn Autorów”, początkowo „Anarchistyczny Magazyn Autorów”). Od 1994 roku w ramach pisma ukazywała się wkładka muzyczna poświęcona głównie niezależnej scenie punkrockowej i hardcore. „Мать Парядка" ukazywała się w różnych formatach od A3 do B5 (najdłużej jako A5) i miała także różną objętość od ok. 20 do prawie 100 stron.

\section{/// Pokoleniowa zmiana}

W latach 90. w obrębie działań kontrkulturowo-alternatywnych w Polsce pojawily się nowe zjawiska, których próżno szukać w latach wcześniejszych. Wpisywały się one w profil nowych środowisk i działań. Najczęściej były reakcją na zmieniająca się gwałtownie pokomunistyczną rzeczywistość, ale równocześnie podejmowano działania, które odnosiły się do

\footnotetext{
1 Ruch Społeczeństwa Alternatywnego (RSA) - jedna z ważniejszych polskich organizacji anarchistycznych w drugiej połowie XX wieku. Założona w Gdańsku na początku lat 80. (Manifest RSA pochodzi z 1983 roku) i posiadająca niesformalizowaną strukturę. Przedstawiała się jako opozycyjna wobec PRL i III RP. RSA był w późniejszych latach m.in. członkiem Międzymiastówki Anarchistycznej, Federacji Anarchistycznej czy Federacji Zielonych (Antonów 2004, Kaczmarek 2009).

2 Wolność i Pokój (WiP) - polska niezależna organizacja pacyfistyczna funkcjonująca w latach 1985-1992 i opozycyjna wobec władz PRL. Główna działalność WiP obejmowała działania pacyfistyczne (przede wszystkim walkę o zapewnienie wojskowej służby zastępczej na żądanie) i na rzecz praw człowieka, a w okresie schyłkowym także ekologiczne (protesty przeciwko budowie Elektrowni Jądrowej w Żarnowcu i zapory wodnej w okolicach Czorsztyna) (Smółka-Gnauck 2012).
} 
sfery idei, stylu życia, wartości postmaterialnych (ekologia) czy progresywnych (feminizm, prawa mniejszości seksualnych czy etnicznych).

Stosunek do nowych realiów od początku dzielił aktywistów z lat 80 . i 90. Sprzeciw młodych ludzi wobec kapitalizmu w latach 90. może wydawać się jednak jak najbardziej uprawomocniony. Gwałtowne zmiany systemowe po 1989 roku sprawiły, że społeczeństwo (w tym młodzi ludzie) poddane zostało terapii szokowej, w wyniku której poziom życia dużych grup społecznych uległ gwałtownemu pogorszeniu, a w wielu przypadkach doszło wręcz do ich wykluczenia.

W następstwie tych zjawisk uwaga nowej kontrkultury w dużym stopniu skierowana została na krytykę lansowanej przez władzę i media polityki społeczno-gospodarczej, która z czasem rozwinęła się w sprzeciw wobec gospodarki wolnorynkowej i szerzej liberalizmu (w tym głównie jego neokonserwatywnej wersji realizowanej w Polsce od 1989 roku).

Jako że w latach 80. kontrkultura nie wypracowała alternatywnej formuly, poza krytyką systemu komunistycznego, jej przedstawiciele w zdecydowanej większości poparli, a często wręcz wsparli, neokonserwatywno-liberalne zmiany w Polsce. Każe to interpretować kontrkulturę z lat 80. raczej jako rewoltę o liberalno-demokratycznym i kapitalistycznym charakterze, nie zaś jako klasyczną kontrkulturę znaną z Zachodniej Europy i USA. Czytając teksty z fanzinów, można było odnieść wrażenie, że reformy w Polsce były zdecydowanie za wolne i zbyt powierzchowne. Szczególną rolę w kształtowaniu takich opinii odgrywała „Мать Парядка”, na łamach której przez cały czas istnienia pisma (od 1990 do 2002 roku) promowano koncepcje skrajnego liberalizmu, chociażby poprzez przedruki libertariańskich tekstów, głównie dotyczących ekonomii i gospodarki, opierających się na teoriach Miltona Friedmana (np. David Bergland Podatki to keradzięr, csyli ABC libertarianizmu) i M. A. Hayeka (np. Nick Elliot Usiywanie $i$ nadusywanie pieniadza).

$\mathrm{Z}$ polskich autorów szczególną rolę w promowaniu tych neokonserwatywnych teorii odegrał Jacek Sierpiński, którego autorskie teksty (lub tłumaczenia tekstów obcych) były publikowane w każdym numerze periodyku. Sierpiński bronił polityki gospodarczej Pinocheta w Chile i pośrednio jego rządów, będących według autora lepszą alternatywną niż legalna władza prezydenta Allende (1995: 16-19). Jednak najczęściej Sierpiński wskazywał na zbyt powolne reformy i nadal jego zdaniem zbyt duży udział państwa nie tylko w gospodarce, lecz także w życiu społecznym. Sztandarowym tego przykładem jest tekst Im wiekksay budžet państwa, tym mniejsze budizety domowe, gdzie Sierpiński pisze wprost o potrzebie likwidacji państwowej służby zdrowia, oświaty, ZUS-u, gospodarki komunalnej, zabytków 
itp. i oddania ich pod kontrolę wolnego rynku (1993: 8-12). Skojarzenia z postulatami Unii Polityki Realnej sa jak najbardziej wskazane, bo w jednym $z$ numerów tego, jak by nie patrzeć, anarchistyczno-wolnościowego periodyku znalazł się wywiad z Januszem Korwin-Mikkem (1993, nr 8 (luty): 27-28), zachęcający de facto do głosowania na UPR.

Działacze lat 80. dość wyraźnie wsparli formowanie nowego systemu. Znamienny był przykład działaczy pacyfistycznej organizacji Wolność i Pokój, której czołowi przedstawiciele brali udział np. w tworzeniu Urzędu Ochrony Państwa. Niegdysiejsi kontrkulturowcy włączali się także w oficjalna działalność polityczna i - co charakterystyczne - najczęściej wybierali (i wybieraja po dziś dzień) partie prawicowe i prawicowo-centrowe. W latach 90. były to Unia Demokratyczna (potem Unia Wolności), Akcja Wyborcza Solidarność, Kongres Liberalno-Demokratyczny, Unia Polityki Realnej, Liga Republikańska czy nawet Zjednoczenie Chrześcijańsko-Narodowe.

Innym szerokim polem aktywności osób zaangażowanych w latach 80 . w działalność kontrkulturową był obszar mainstreamowej kultury i oficjalnych mediów. Nieprzypadkowo okres szerokiego udziału osób wywodzących się ze środowisk kontrkultury lat 80 . w mediach publicznych (chodzi zarówno o obsadę stanowisk, jak i przygotowywanie programów, np. telewizyjnych „AlternaTiVi”, „Dzyndzylyndzy” czy „Lalamido”) przypadał na czas rządów konserwatywnej prawicy (1992-1993).

To szybkie i w zasadzie bezrefleksyjne zaakceptowanie nowych realiów, nie tylko polityczno-ekonomicznych, ale także społeczno-kulturowych, każe zastanowić się, czy wartości postmaterialne utożsamiane z kontrkulturą lat 80 . rzeczywiście były wynikiem autentycznych wyborów, czy zostały raczej wymuszone przez realia gospodarki permanentnego niedoboru. Kapitalizm, liberalizm i wolny rynek były tym, czego spora część młodzieży dorastającej lub aktywnej w latach 80. chciała i pragnęła. Kojarzyły się one ze zmitologizowana przez popkulturę wersją wolnego życia na Zachodzie, który w okresie schyłkowego PRL-u był dla młodych ludzi wyznacznikiem wszystkiego, co normalne i naturalne.

Z tej perspektywy ciekawie prezentują się postawy wobec problemów o charakterze ekologicznym. W latach 80 . ochrona środowiska znalazła się w kręgu zainteresowań środowisk kontrkulturowych i alternatywnych niejako przypadkiem. Miała charakter wyizolowanych i nie do końca uświadomionych pojedynczych działań. Problemy ekologiczne rozpatrywano częściej w kontekście kolejnego frontu walki z systemem komunistycznym. Było to widoczne szczególnie w odniesieniu do największej oddolnej ekologicznej organizacji społecznej w PRL-u, a mianowicie Polskiego 
Klubu Ekologicznego powstałego w 1980 roku, który jako jedna z niewielu organizacji społecznych nie został zdelegalizowany w czasie stanu wojennego. W związku z tym przyciagał on osoby, które nie mogły realizować się w zdelegalizowanej Solidarności (Hrynkiewicz 1990: 12-13). Po przełomie roku 1989 dość charakterystyczne było ogólne wsparcie starych środowisk ekologicznych dla nowej władzy czy to na niwie instytucjonalnej, czy też partyjnej, przejawiające się deklarowanym i rzeczywistym poparciem w kolejnych wyborach, dotyczyło to głównie środowisk skupionych wokół Unii Demokratycznej (np. Gawlik 1993: 13, Hyła 1997: 8, Perkowski 1997: 88-90).

W kontekście działań alternatywnych w latach 90. można było zauważyć rozminięcie się postulatów ekologicznych, dotyczących np. polityki transportowej i energetycznej, ochrony Puszczy Białowieskiej, zapory w Czorsztynie czy budowy elektrowni atomowej w Żarnowcu, wyrażanych przez nowe grupy i środowiska, z reakcjami kolejnych ekip rządzących, również tych, które w swoich szeregach miały osoby wywodzące się z kontrkultury lat 80., w tym na stanowiskach decyzyjnych (np. w ówczesnym Ministerstwie Ochrony Środowiska Naturalnego). Władze najczęściej ignorowały te postulaty, a jeśli już reagowały, to wysyłały przeciwko protestującym oddziały policji (Gliński 1996: 208).

W latach 90. środowiska nowej kontrkultury jako jedne z pierwszych zaczęły także wprowadzać w obszar przestrzeni publicznej elementy polityki emancypacyjnej, a konkretnie feminizm, prawa mniejszości seksualnych czy etnicznych.

Nowoczesny feminizm w latach 80. w Polsce praktycznie nie istniał można wręcz powiedzieć, że patriarchat równie mocno był zakorzeniony w tradycyjnym społeczeństwie, co w środowisku kontrkulturowym i alternatywnym. Na przykład w obrębie muzyki alternatywnej rola i miejsce kobiet były takie same jak w przypadku muzyki popularnej. Zredukowano je do biernego odbioru, a nie tworzenia (np. na kilkaset działających w Polsce w latach 80. zespołów punkowych aktywnych muzycznie było jedynie ok. 20-30 młodych kobiet - por. Wasążnik i Jarosz 2010: 215). Młode kobiety dopuszczano jedynie do działalności pomocniczej, stereotypowo kojarzonej z aktywnością kobieca (np. robienie zdjęć czy przygotowywanie posiłków). W gruncie rzeczy jednak kobiety były dodatkiem do męskiego buntu.

To przedmiotowe traktowanie kobiet było także widoczne w tekstach piosenek, a szczególnie w jednym dość specyficznym nurcie piosenek o przesłaniu antyaborcyjnym. W tych tekstach kobiety przedstawiane były najczęściej jako „matki zbrodniarki” (utwór Prawo do \&̇ycia, çyli kochanej 
mamusi grupy Prowokacja) czy „matki zabijające swoje dzieci” (utwór Czarna droga grupy Bakszysz).

W latach 90. wyrażane przez młode kobiety postulaty polityki równościowej przez wielu działaczy z poprzedniej dekady traktowane były jako niebezpieczne i niezgodne $z$ duchem wolnościowym. Co więcej, w tekstach często zwracano uwage na to, że w Polsce to mężczyźni są bardziej dyskryminowani (sic!) niż kobiety (argumentem miała być przymusowa służba wojskowa i wyższy wiek emerytalny - por. np. Sierpiński 1994: 12-14 i Sierpiński 1998b: 31-33). Zdarzały się także teksty skrajnie szowinistyczne, np. w jednym autor udowadniał, że zatrudnianie przez mężczyzn ładnych kobiet, ale niemających odpowiednich kwalifikacji, zamiast tych z kwalifikacjami (jak zakładał sam autor, są one zazwyczaj brzydsze) jest działaniem jak najbardziej racjonalnym, a możliwość popatrzenia sobie w pracy na ładną kobietę jest przywilejem mężczyzny (Sierpiński 1996: 21). Zastanawiać może fakt, że w tego typu sytuacjach redakcja nie zamieszczała żadnych komentarzy czy tekstów polemicznych, co każe podejrzewać, że z tego typu opiniami się zgadzała. Nie prezentowano tam także punktu widzenia kobiet. W omawianej „Mać Pariadce” pierwszy tekst napisany na potrzeby czasopisma i podpisany przez kobietę ukazał się dopiero w 1999 roku, a więc 9 lat od powstania magazynu (Spud (Marta) 1999: 13-15).

Podobnie rzecz miała się w przypadku praw mniejszości seksualnych. Tematyka ta pojawiła się w kręgu zainteresowań działaczy alternatywnych w latach 90. I także tutaj reakcja starszych działaczy przybierała często charakter homofobiczny, poczynając od używanego w tekstach języka, a kończąc na stereotypowych argumentach. Sztandarowym tego przykładem jest tekst Artura Psika Wojsko dla gejów! - ten w założeniu prześmiewczy tekst jest tak naprawdę homofobicznym atakiem na homoseksualistów. Autor apeluje, by do wojska powoływać wyłącznie gejów, bo tylko oni chcą tam służyć, dzięki czemu mogliby wtedy do woli oddawać się kontaktom homoseksualnym (1993: 4). Temat homoseksualizmu w kontekście armii w „Мать Парядка” przywoływany był jeszcze kilkakrotnie, np. w numerze 3-4(68) z 1998 roku na stronie 2 pojawiła się antywojskowa reklama ze zdjęciami żołnierzy z poboru z podpisami: „Idź do woja znajdziesz boja!!!” i „Wojsko rozwija więzi między mężczyznami”.

Jeszcze ostrzej na temat praw homoseksualistów wypowiadał się Stefan J. Adamski, którego tekst zawiera elementy czysto homofobiczne zarówno w treści (np. w kwestii ewentualnych adopcji dzieci przez pary homoseksualne pisał: „uważam, iż dopuszczali by się oni czynów niewłaściwych wobec podopiecznych”, 1994: 56), jak i na poziomie języka: $\mathrm{w}$ tytule Terror tolerancij, csyli uwag kilka w kwestii praw odmieńców, i w samym 
tekście, gdzie na określenie gejów i lesbijek używa terminów obraźliwych: „pedały” i „pederaści” (1994: 55).

Innym specyficznym obszarem, gdzie dość wyraźnie rozmijały się poglądy sporej części osób zaangażowanych w kontrkulturę w latach 80. i 90., był stosunek do takich pojęć, jak Polska, patriotyzm, naród czy nacjonalizm. W wytworach kontrkultury z okresu PRL-u dominował charakterystyczny i specyficzny stosunek do tych kwestii. Postawy patriotyczne nie należały do wyjątków, a duma z narodu stawiającego opór komunizmowi była wręcz obowiązkowym elementem kontrkulturowej tożsamości. Tak naprawdę każdy zespół z tego nurtu miał w swoim repertuarze przynajmniej jeden utwór do tego się odwołujący (np. Moskwa Nigdy, Aurora Polska, Kult Polska, Sztywny Pal Azji Spotkanie z). Próżno takich utworów szukać wśród zespołów i wykonawców, którzy zaczęli działać w latach 90. Wręcz przeciwnie. Wtedy takie pojęcia, jak Polska, naród czy patriotyzm, były przez tę nową kontrkulturę zastępowane bezpaństwowością czy kosmopolityzmem.

Zwracano za to uwage na tematy całkowicie ignorowane w oficjalnym obiegu kultury, takie jak narastające zachowania i postawy nacjonalistyczne, antysemickie czy rasistowskie. I znowu różnice między dwiema generacjami aktywistów dość wyraźnie widoczne były na łamach fanzinów.

$\mathrm{Na}$ przykład teksty Jarosława Tomasiewicza publikowane w „Zielonych Brygadach” i „Mać Pariadce” w widoczny sposób broniły idei narodowych, a często zawierały elementy nacjonalistyczne. W tekście Wyznanie nonkonformisty pisze on: „Uważam, że na godność każdego człowieka składa się nie tylko duma z jego indywidualności, ale także duma z przynależności do pewnych zbiorowości, takich jak choćby naród. Kosmopolici, plujący na miejsce, w którym wyrośli, i ludzi, z którymi los ich związał, są pozbawieni części swej godności” (Tomasiewicz 1993: 19). W innym fragmencie tekst staje się pochwałą mizoginii, ksenofobii czy postaw rasistowskich, gdy autor pisze: „Uważam za przerażający świat, w którym kobiety i mężczyźni, dzieci i dorośli, biali i czarni są jednakowi” (tamże: 19).

W podobnym tonie utrzymany był również tekst Jarosława Trojana Trzecia Droga - od faszyzmu ku anarchizmowi?, w pozytywny sposób przybliżający nacjonalistyczno-separatystyczną brytyjską organizację Third Way, wywodząca się ze skrajnie nacjonalistycznego Frontu Narodowego (Trojan 1993: 29-31). Innym przykładem przemycania treści nacjonalistycznych były materiały dotyczące wierzeń prasłowiańskich publikowane pod szyldem antykatolicyzmu. Teksty te w mniej lub bardziej zawoalowany sposób odwoływały się do organizacji nacjonalistycznych z okresu II RP, jak np. było to w tekście pt. Zadruga (Wacek 1994: 18-20). 
W „Mać Pariadce” treści konserwatywne, nacjonalistyczne czy narodowe próbowano także przemycać przy okazji tekstów (zarówno tłumaczeń, jak i własnych) dotyczących środowiska paramilitarnych organizacji amerykańskich separatystów (zwanych popularnie milicjami). Przychylnie oceniano możliwość uzbrajania się przez jej członków, chwalono reprezentowane przez nie tendencje separatystyczne, samorządność etc. Równocześnie jednak pomijano ich rasistowski, ksenofobiczny, homofobiczny, religijny i konserwatywny charakter (np. Sierpiński 1995: 16-19, Sierpiński 1998a: 109-116).

Można oczywiście tego typu teksty traktować jako swoiście pojmowany pluralizm w prezentowaniu tematów przez fanzinowe redakcje. Niemniej wydaje się, że powinny one zostać opatrzone odredakcyjnym komentarzem lub chociaż informacja, że tego typu poglądy nie reprezentuja stanowiska redakcji.

\section{/// Podsumowanie}

Reasumując, można stwierdzić, że kontrkultura z lat 80. w świetle działań kluczowej części jej animatorów prezentuje się raczej jako kolejna wersja liberalno-demokratycznego protestu przeciwko autorytarnym rządom niż jako kontrkultura sensu stricto. Można wręcz odnieść wrażenie, że ponieważ kontrkultura lat 80 . nie wypracowała żadnej alternatywy wobec komunizmu, jej przedstawiciele tak chętnie poparli neokonserwatywne w duchu i liberalne w treści reformy po roku 1989. Innymi słowy, ten deklarowany przez kontrkulturę lat 80 . fundamentalny antykomunizm naturalnie pchnął część jej przedstawicieli na pozycje konserwatywne czy wolnorynkowe.

Konsekwencje takich postaw są aż nadto widoczne, zważywszy na stosunkowo dużą masowość i popularność kontrkulturowo-alternatywnych treści w okresie przełomu. W oparciu o kontrkulturę z lat 80. nie powstał żaden zinstytucjonalizowany lub przynajmniej nią inspirowany masowy ruch społeczny, siła polityczna ani prąd myślowy, który miałby jakikolwiek wpływ na realia społeczno-polityczno-kulturowe w Polsce po 1989 roku. Nie doszło do „przewietrzenia” postkomunistycznego społeczeństwa. Jednym z efektów widocznych po dziś dzień jest brak nowoczesnej i silnej lewicy (czy szerzej partii alternatywnej jak Zieloni), czyli elementu trwałego i ważnego w systemach politycznych świata zachodniego, a więc wszędzie tam, gdzie istniała kontrkultura lat 60. Powstanie nowoczesnej lewicy, czyli siły, która mogłaby zrównoważyć dominującą 
w Polsce myśl konserwatywną, byłoby również ważnym elementem modyfikującym zmiany systemowe i modernizację w Polsce.

Polska kontrkultura lat 80 . nie ma bogatej i przede wszystkim różnorodnej bibliografii naukowej. Dominują szablonowe, czarno-białe biografie i wspomnienia pisane najczęściej przez samych uczestników lub zaprzyjaźnionych dziennikarzy (głównie muzycznych). Jednak wszystkie one pisane są z dzisiejszej perspektywy, w związku z czym tworzą dość spójny, ale równocześnie nie do końca prawdziwy, a raczej wyobrażeniowy i pożądany obraz wydarzeń z przeszłości.

Brakuje obszernych, szczegółowych i obiektywnych badań naukowych. Byłyby one wskazane, bo jak starałem się pokazać w niniejszym tekście, obraz kontrkultury lat 80. nie jest tak jednorodny i jednoznaczny, jak się go powszechnie przedstawia. Można to zobaczyć dzięki całkowicie zapomnianym źródłom informacji, jakimi sa fanziny. Materiały tam zawarte nie dość, że pochodza z pierwszej ręki, to jeszcze osadzone są w ówczesnych realiach, a opisywany w nich świat kontrkultury jest znacznie bliższy prawdy niż zdecydowana większość współczesnych publikacji.

Bibliografia:

/// Adamski S. J. 1994. Terror tolerancij, çyli uwag kilka w kwestii praw odmieńców, „Мать Парядка” 1994, nr 4(22), s. 54-56.

/// Antonów R. 2004. Pod czarnym sztandarem. Anarchizm w Polsce po 1980 roku, Wydawnictwo Uniwersytetu Wrocławskiego, Wrocław.

/// Brylewski R. 2012. Krysys w Babilonie. Autobiografia (rozmawia Rafat Ksiesylk), Wydawnictwo Literackie, Kraków.

/// Ciosmak D., opr. 2001. Antologia zinón 1989-2001, Wydawnictwo Liberation, Kielce.

/// Dąbrowska-Lyons A. 1999. Polski punk 1978-1982, Agencja Promocyjno-Wydawnicza „Ada”, Warszawa.

/// Fatyga B. 1999. Dricy z. naszej ulicy. Antropologia kultury mtodzieżowej, ISNS UW, Warszawa.

/// Gawlik R. 1993. UD prosi o pomoc, „Zielone Brygady” 1993, nr 9(51), s. 13.

/// Gliński P. 1996. Polscy Zieloni. Ruch spoteczny w okresie præemian, Wydawnictwo IFiS PAN, Warszawa. 
/// Gnoiński L., Skaradziński J. 2001. Encyklopedia polskiego rocka, In Rock, Poznań.

/// Gortat R. 1987. O naturze nowych ruchów spotecznych, [w:] Studia nad ruchami spolecznymi, red. E. Lewicka-Banaszak, P. Marciniak, W. Modzelewski, UW Instytut Socjologii, Warszawa.

/// Grabowski K. 2010. Dezerter. Poroniona generacja?, Agora, Warszawa.

/// Grabowski K. („Grabaż”). 2010. Gościu. Auto-bio-Grabaそ், In Rock, Poznań.

/// Hrynkiewicz J. 1990. Zieloni. Studia nad ruchem ekologicznym w Polsce 1980-1989, UW Instytut Socjologii, Warszawa.

// / Hyła M. 1997. Divided We Fall?, „Green Brigades” 1997, nr 1(24), s. 8.

/// Idzikowska-Czubaj A. 2006. Funkcje kulturowe i bistoryczne znaczenie polskiego rocka, Wydawnictwo Literackie, Poznań.

/// Janiszewski J., Końjo P., Skiba, K. 2010. Artyści, wariaci, anarchiści, Narodowe Centrum Kultury, Warszawa.

/// Jawłowska A. 1975. Drogi kontrkultury, Państwowy Instytut Wydawniczy, Warszawa.

/// Jesswein R. 1985. Trzeci obieg. Trzecie pokolenie 1945-1985, „Odra” 1985, nr 3 .

// / Kaczmarek D., red. 2009. Ruch Społeczeństwa Alternatywnego 1983-1991, Wydawnictwo Biblioteki Anarchistycznej, Poznań.

/// Kajtoch W. 1999. Świat prasy alternatywnej w zwierciadle jej stownictwa, Wydawnictwo Uniwersytetu Jagiellońskiego, Kraków.

/// Konnak P. 2012. Gangrena. Mój punk rock song, Narodowe Centrum Kultury, Warszawa.

/// Konnak P. 2013. Karnawat profuziji, Narodowe Centrum Kultury, Warszawa.

/// Lenart B. 1993. Etos kontestujacych ruchón mtodzieżonych hippies i punk w latach 80. w Polsce. Analiza porównawcza, „Kultura i Społeczeństwo” 1993, nr 3.

/// Perkowski T. 1997. Make Love Not War, Man! (Facet, uprawiaj mitość, nie wojne!), „Zielone Brygady” 1997, nr 11(101), s. 88-90.

/// Pęczak M. 1988a. Kilka uwag o træẹch obiegach, „Więź” 1988, nr 2. 
/// Pęczak M. 1988b. O wybranych formach komunikowania alternatywnego w Polsce, „Kultura i Społeczeństwo” 1988, nr 3.

/// Pietia. 1989. Kolumna, „QQRYQ” 1989, nr 12, s. 3-4.

/// Psik A. 1993. Wojsko dla gejów!, „Мать Парядка” 1993, nr 9 (marzec), s. 4-6.

/// Sierpiński J. 1993. Im wiekeszy budżet państwa, tym mniejsz̧e budżety domowe, „Мать Парядка” 1993, nr 9 (marzec), s. 8-12.

/// Sierpiński J. 1994. Feminizm na manowcach, „Мать Парядка” 1994, nr 3(21), s. 12-14.

/// Sierpiński J. 1995. Kilka uwag na temat kilku uwag, „Мать Парядка” 1995, nr 12(42), s. 16-19.

/// Sierpiński J. 1996. Kobiety, seks i pieniqdze, „Мать Парядка” 1996, nr 4(46), s. 21-22.

/// Sierpiński J. 1998a. „Antyfaszysci”” Zastanówcie się! Stowo w obronie niestusznie oskarzonych o fasayzm, „Мать Парядка” 1998, nr 1-2(67), s. 109-116.

/// Sierpiński J. 1998b. Prayjdzie urzelnik i uyrówna, „Мать Парядка” 1998, nr 12(72), s. 31-33.

/// Smółka-Gnauck A. 2012. Między wolnościq a pokojem. Zarys historii Ruchu „Wolnośc i Pokój”, Instytut Pamięci Narodowej, Warszawa.

/// Spud M. 1999. Osiemnasty, „Mać Pariadka” 1999, nr 3, s. 13-15.

/// Staszczyk M. 2011. Muniek (z. Zygmuntem Staszczy)iem rozmawia Grzegorz Brzozowicz), Wydawnictwo Czerwone i Czarne, Warszawa.

/// Szczygieł M. 1989. Xeroxy, „Na przełaj” 1989, nr 51/52 (31.12.89), s. $9-10$.

/// Tomasiewicz J. 1993. Wyгnanie nonkonformisty, „Мать Парядка” 1993, nr 7, s. 19-20.

/// Trojan J. 1993. Trzecia Droga - od faszyzmu ku anarchizmowi?, „Мать Парядка" 1993, nr 8 (luty), s. 29-31.

/// Wacek A. 1994. Zadruga. „Мать Парядка” 1994, nr 5(23), s. 18-20.

/// Wasażzik M., Jarosz R. 2010. Generacja, Korporacja Ha!art, Warszawa. /// Wertenstein-Żuławski J., Słodkowska I. 1987. No future?, „Więź” 1987, nr 6.

/// Wyka A. 1987. Przedmowa, [w:] Punkt zurotny. Nauka, spoleczeństwo, nowa kultura, F. Capra, Państwowy Instytut Wydawniczy, Warszawa, s. 5-27. 


\section{/// Abstrakt}

Polska kontrkultura z lat 80. miała dość specyficzny charakter, który nie do końca odpowiadał ówczesnym działaniom kontrkulturowo-alternatywnym na Zachodzie. Przejawiało się to przede wszystkim w deklarowanym antykomunizmie (i szerzej antylewicowości), ale także w zachowawczym podejściu do kwestii światopoglądowych (np. wyznawana religijność) czy braku postaw emancypacyjnych (np. w obszarze feminizmu czy praw mniejszości seksualnych). Alternatywny obieg (czyli działanie poza oficjalnymi kanałami) często w dużym stopniu wynikał z trudności obiektywnych (ograniczenia systemu komunistycznego), a deklarowane przez uczestników zasady i wartości były jedynie tego konsekwencja. Autentyczna kontrkultura w tradycyjnym tego słowa znaczeniu zaczęła krystalizować się dopiero w latach 90., gdy pojawiło się nowe, młodsze pokolenie aktywistów. Widać to wyraźnie na przykładzie analizy treści zawartych $\mathrm{w}$ fanzinach wydawanych w drugiej połowie lat 80 . i na początku lat 90 .

Słowa kluczowe:

kontrkultura, fanziny, trzeci obieg, kultura alternatywna.

\section{/// Abstract}

Polish counterculture from the 80 s had a quite specific character which was considerably different from the counterculture and alternative activities undertaken in the Western World. The aforementioned discrepancy was mostly visible in a declared anticommunist (and, in a broader sense, anti-leftist) attitudes, but also in the conservative world view (declared religiousness), lack of emancipation attitudes (for instance, in the realm of feminism or sexual minorities). Even the alternative circulation (outside the official channels) was more often chosen because of the objective difficulties caused by the communist system constrains. Due to that, declared by the activists principles and values were just a consequence of the existing situation. The authentic counterculture (in a way it is described in the West) started to crystalize in Poland only in the 90s. It was due to the new (younger) generation of activists that emerged back then. It is clearly visible upon analyzing the articles in underground fanzines from the late 80 s and the early 90 s.

Keywords:

counterculture, fanzines, third circulation, alternative culture 